\title{
Step Counts of Middle-Aged and Elderly Adults for 10 Months Before and After the Release of Pokémon GO in Yokohama, Japan
}

Kimihiro Hino ${ }^{1}$, PhD; Yasushi Asami ${ }^{1}, \mathrm{PhD}$; Jung Su Lee ${ }^{2}, \mathrm{PhD}$

${ }_{1}^{1}$ Department of Urban Engineering, Graduate School of Engineering, The University of Tokyo, Bunkyo-ku, Tokyo, Japan

${ }^{2}$ Department of Public Health, Graduate School of Medicine, The University of Tokyo, Bunkyo-ku, Tokyo, Japan

Corresponding Author:

Kimihiro Hino, $\mathrm{PhD}$

Department of Urban Engineering

Graduate School of Engineering

The University of Tokyo

7-3-1 Hongo

Bunkyo-ku, Tokyo, 113-8656

Japan

Phone: 81358416225

Email: hino@ua.t.u-tokyo.ac.jp

\section{Abstract}

Background: Smartphones have been integrated into our society and are expected to serve as tools to improve health outcomes. In the summer of 2016, Pokémon GO, a location-based augmented reality game for smartphones was released; it attracted attention from the perspective of health, especially with its potential to increase physical activity (PA). A few studies have compared objectively measured step counts before and after the release of the game; however, they were conducted over a short study period and evaluated only young people.

Objective: The objective of this study was to confirm whether there was a difference in step counts between middle-aged and elderly players and nonplayers before and after the release of Pokémon GO.

Methods: A total of 46 players and 184 nonplayers aged $\geq 40$ years were matched for sex, age group, and PA level; they were respondents to a questionnaire randomly sent to citizens who were given free pedometers by Yokohama city. Their play status was identified through the questionnaire. To investigate the change in step counts before and after the release of Pokémon GO according to play status, a 2-way repeated-measures analysis of variance was performed. Step counts 1 month before the release of the game were compared with those 8 months after the release. In addition, subgroup analyses according to sex, age group, PA level, and subjective health status were performed.

Results: The mean ages of players and nonplayers were 56.5 (SD 9.9) years and 57.3 (SD 9.6) years, respectively, and the mean baseline step counts of players and nonplayers were 7641.8 (SD 2754.5) and 7903.3 (SD 2674.7), respectively. There was no significant difference in the age and baseline step counts according to a t test (2-tailed). In the analysis of all samples, the interaction between play status and time effect was significant for 3 of 8 months after release. In the subgroup analyses, the interaction was significant for 3 months in men, 7 months in the 55-64-year-old group, 2 months in workers, 4 months in the active group in PA level, and 2 months in participants with subjectively good health. The interaction was significant for only 1 month, at most, in other subgroups.

Conclusions: The present study confirmed a difference in step counts between players and nonplayers before and after the release of Pokémon GO. According to our analysis, step counts were higher until 7 months after the release. The player group maintained their step counts in winter, despite the decrease in step counts of nonplayers. In subgroup analyses, players were more likely to be men, aged $<55$ years, workers, active, and subjectively in good health.

(J Med Internet Res 2019;21(2):e10724) doi: 10.2196/10724

\section{KEYWORDS}

augmented reality; location-based games; mobile phone; pedometer; physical activity; Pokémon GO; smartphone 


\section{Introduction}

\section{Background}

Smartphones have become integrated into our society and can serve as tools to improve health outcomes [1], especially in increasing physical activity (PA), which, in turn, is associated with physical and mental health [2]. However, until a few years ago, most apps incorporated few behavioral change techniques, such as feedback on behavior [3,4], and only a few studies have assessed the effects on PA of interventions using smartphone technology [5-7].

Pokémon GO is a location-based augmented reality game for smartphones released in the summer of 2016. According to the Guinness World Records, it was the "most downloaded mobile game in its first month" [8] and was the number 1 free app in 36 countries [9]. Although the combination of location-based service and augmented reality is not novel, Pokémon GO attracted attention because of the perfect incorporation of technology into the story within the game [10]. Players are encouraged to walk outside to catch Pokémon characters, hatch their eggs, and acquire game items by visiting Pokéstops and Gyms.

The game has attracted attention from the perspective of health [11-16] as a "game changer" for the physical inactivity crisis [17]. Pokémon GO players collectively walked 4.6 billion kilometers in only 8 weeks, surpassing 500 million downloads worldwide [18]. Twitter postings demonstrated that Pokémon GO players walked $>30$ minutes a day [19], and the game even changed peoples' hot-spots [20] and the general mobility patterns [21] in cities.

\section{Previous Studies}

For Pokémon GO players, health or PA is an important and unique motivation to play, which is not usually the case in other Web-based gaming [22-24]. In addition, positive outcomes have been observed in not only PA seekers but also players with other motivations for playing [25].

From the viewpoint of psychological health, Pokémon GO moderated psychological distress [26] and social anxiety [27], as well as increased place attachment [28]. These psychological factors relate to behavioral consequences; enjoyment of Pokémon GO remarkably resulted in perceived increases in outdoor PA [29].

Some studies used the International Physical Activity Questionnaire to report an increase in PA in players after playing Pokémon GO [22,30,31]. Several other studies used different questionnaires and reported an increase in PA frequency and duration [32], increase in PA and decrease in sedentary behaviors [33], and increase in time spent walking dogs [34]. However, self-serving bias cannot be avoided when using self-reported measurements [35-37].

Some studies have compared objectively measured step counts using a pedometer or an accelerometer, which can explain most of the variation in PA [38] before and after playing Pokémon GO. One study compared the number of daily steps taken by players and nonplayers for 4 weeks before and 6 weeks after installation of Pokémon GO. That study concluded that step counts moderately increased after installation of the game, but this result was no longer observed 6 weeks after installation [39]. Another study compared players' step counts 3 weeks before and 3 weeks after the Pokémon GO release date and observed the largest increases in participants who spent more time playing, who were overweight or obese, or who had a low baseline PA level [40]. However, both of the abovementioned studies measured the number of step counts using the iPhone Health app, which has considerable difference from the accelerometer under free-living conditions [41]. Another study used Microsoft Band, which includes a 3-axis accelerometer and gyrometer, and observed that players identified through Microsoft's search engine queries had notably increased PA over an observation period of approximately 4 weeks [42].

\section{Study Aim}

This study aimed to confirm whether there was a difference in step counts between middle-aged and elderly players and nonplayers before and after the release of Pokémon GO in Japan. The long-term impact of the game on PA should be examined; however, previous studies have evaluated its impact for only several weeks $[42,43]$. The uniqueness of this study lies in its long survey period (10 months), use of a pedometer, and focus on middle-aged to elderly people, while most previous studies focused on younger people $[30,31,33,44]$. As PA patterns change by age [45], the impact of the game for middle-aged people, who tend to be more occupied with social responsibilities, and for elderly people after retirement is expected to be different than the impact on younger people. Pokémon GO was released in Japan on July 22, 2016.

\section{Methods}

\section{Yokohama Walking Point Program}

Yokohama city is the second largest city in Japan, with a population of approximately 3.7 million and a humid subtropical climate with 4 distinct seasons. The city launched the Yokohama Walking Point Program (YWPP) in November 2014 to encourage citizens to improve their health and enjoy a healthy life expectancy, as the population ages and the disease structure changes in Japan.

A free pedometer (Omron HJ-326F, Japan) was given to citizens aged $\geq 18$ years who volunteered to participate in the program. Participants were awarded points by scanning their pedometers via special readers installed at approximately 1000 stores and other facilities in the city. Accumulation of a certain number of points made participants eligible to win prizes. The scanned data were sent to a data server through the internet, and participants could monitor step counts and rank among all participants using a computer or a smartphone [46].

\section{Pedometer Data}

Pedometer data, which were collected from 231,606 YWPP participants who registered before March 31, 2017, were used in this study. The daily mean step count for each month was calculated for each participant using the monthly step count and the number of days recorded for that month. Data on sex and 
date of birth were obtained from registered information, and age as of May 31, 2016, was considered.

\section{Questionnaire}

In May 2017, Yokohama city conducted a questionnaire survey among 2580 participants, who were randomly selected among 99,462 individuals who sent their recorded data of $>80 \%$ days after registration; among the selected participants, 2055 replied to the survey (response rate 2055/2580, 79.65\%). The questionnaire data and the pedometer data were combined in the analysis.

The questionnaire mainly asked about the change in participants' walking habit and health attitude as well as their use of "smartphone game apps in which players catch characters and occupy bases using location services." Participants who selected the first of 4 options ranging from "frequently" to "not at all" in a question on the frequency of use of such smartphone game apps were regarded as "players" and others as "nonplayers" in this study. Regarding occupation, participants were classified into workers (including part-time employees) and nonworkers. While health status was graded according to 4 points ranging from good to poor, it was also classified into "good" and "others" because the latter two scales (rather poor or poor) were not often selected.

\section{Study Participants}

Among the 2055 participants who replied to the questionnaire, those who had records of limited days or had abnormal records were excluded. First, 1079 participants with pedometer data for $<10$ days per month in any month from June 2016 to March 2017, except July 2016 (which was when Pokémon GO was released in Japan), were excluded. In addition, 62 participants whose step counts in any of those months were out of the range of the mean (SD 2) in all samples were excluded as outliers.

Among the remaining 914 participants, 46 (5.0\%) were game players. Among nonplayers, 184 participants, which was equivalent to 4 times the number of players, were randomly selected so that the ratio of players to nonplayers was 1:4 after stratification by sex, age group $(<55,55-64$, and $\geq 65$ years), and PA level. We considered the age of 65 years as the threshold for elderly persons in Japan, with the employment rate decreasing the most at this age. Participants aged $<65$ years were divided into 2 groups so that the numbers of participants in the 2 groups were similar. The participants' PA level was based on whether their baseline step counts were higher than the target in the Japanese national health promotion plan (men aged $<65$ years, 9000 ; women aged $<65$ years, 8500 ; men aged $\geq 65$ years, 7000; women aged $\geq 65$ years, 6000) [47]. Finally, a total of 230 participants were included in the analysis.

\section{Statistical Analysis}

To investigate the change in step counts before and after the release of Pokémon GO according to play statuses, a 2-way repeated-measures analysis of variance was performed. Step counts in June 2016 (baseline) were compared with those for each month from August 2016 to March 2017. After analysis of all samples, subgroup analyses according to sex, age group, PA level, and subjective health status were performed. The effect of Pokémon GO could be determined based on the interaction between the play status and the time effect. The significance level was set at $P<.05$. Shapiro-Wilk test was used to assess the normality of the distribution of samples' step counts in each group in each month. Levene test was used to assess the homogeneity of variances between groups in each month. All statistical analyses were conducted using IBM SPSS Statistics 23 (IBM Corp).

\section{Results}

\section{Sample Statistics}

Participants' characteristics are presented in Table 1. The youngest participant was 40 years old because YWPP recruited citizens aged 18-39 years since June 2016. The mean ages of players and nonplayers were 56.5 (SD 9.9) years and 57.3 (SD 9.6) years, respectively. The mean baseline step counts of players and nonplayers were 7641.8 (SD 2754.5) and 7903.3 (SD 2674.7), respectively. No significant difference was observed between players and nonpalyers regarding age and baseline step counts using a $t$ test (2-tailed; $P=.56$ and.61, respectively). Although the percentage of players among nonworkers was lower than that among workers, the difference was not significant according to chi-square test $(P=.22)$. Regarding subjective health status, the proportion of participants in good health was almost the same in players and nonplayers.

\section{Analysis of All Samples}

The results of the analyses of all samples are presented in Table 2. Although nonplayers walked more than players by 261 steps per day in June 2016 (baseline), the difference in step counts between the 2 groups got smaller between August and October, and players walked more than nonplayers later on. Time effect was significant in August, September, January, and March, when the step counts of participants decreased compared with that at baseline. The interaction between the play status and time effect was significant in November, December, and February. Although a decrease in step counts was observed in the nonplayer group in winter, the player group maintained their step counts (Figure 1). The largest difference in step counts between players and nonplayers was 583 steps per day in December. 
Table 1. Characteristics of the study participants.

\begin{tabular}{|c|c|c|c|}
\hline Characteristic & Pokémon GO Players, n (\%) & Nonplayers, n (\%) & Total, $\mathrm{n}$ \\
\hline \multicolumn{4}{|l|}{ Sex } \\
\hline Male & $23(20.0)$ & $92(80.0)$ & 115 \\
\hline Female & $23(20.0)$ & $92(80.0)$ & 115 \\
\hline \multicolumn{4}{|l|}{ Age in years } \\
\hline$<55$ & $20(20.0)$ & $80(80.0)$ & 100 \\
\hline $55-64$ & $16(20.0)$ & $64(80.0)$ & 80 \\
\hline$\geq 65$ & $10(20.0)$ & $40(80.0)$ & 50 \\
\hline \multicolumn{4}{|l|}{ Occupation } \\
\hline Worker $^{\mathrm{a}}$ & $33(22.4)$ & $114(77.6)$ & 147 \\
\hline Nonworker & $13(15.7)$ & $70(84.3)$ & 83 \\
\hline \multicolumn{4}{|c|}{ Physical activity level $^{b}$} \\
\hline Active & $17(20.0)$ & $68(80.0)$ & 85 \\
\hline Nonactive & $29(20.0)$ & $116(80.0)$ & 145 \\
\hline \multicolumn{4}{|l|}{ Health status } \\
\hline Good & $17(20.7)$ & $65(79.3)$ & 82 \\
\hline Others $^{c}$ & $29(19.6)$ & $119(80.4)$ & 148 \\
\hline Total & $46(20.0)$ & $184(80.0)$ & 230 \\
\hline
\end{tabular}

${ }^{\mathrm{a}}$ Worker included part-time employees.

b Participants' physical activity level was based on whether their baseline step count was higher than the target in the Japanese national health promotion plan (men aged <65 years, 9000; women aged $<65$ years, 8500 ; men aged $\geq 65$ years, 7000 ; women aged $\geq 65$ years, 6000).

${ }^{\mathrm{c}}$ Others health status included rather good, rather poor, and poor.

Table 2. Results of a 2-way repeated-measures analysis of variance investigating changes in step counts before and after the release of Pokémon GO according to play statuses $(\mathrm{N}=230)$.

\begin{tabular}{|c|c|c|c|c|c|c|}
\hline \multirow[t]{2}{*}{ Time point $^{\mathrm{a}}$} & \multirow[t]{2}{*}{ Players $(n=46)$, mean $(S D)$} & \multirow[t]{2}{*}{ Nonplayers ( $\mathrm{n}=184)$, mean (SD) } & \multicolumn{2}{|l|}{ Time effect } & \multicolumn{2}{|c|}{ Interaction term (timexplayer) } \\
\hline & & & $F$ test $\left(d f_{1}, d f_{2}\right)$ & $P$ value & $F$ test $\left(d f_{1}, d f_{2}\right)$ & $P$ value \\
\hline \multicolumn{7}{|l|}{ Baseline } \\
\hline June '16 & $7642(2754)$ & 7903 (2675) & $\mathrm{N} / \mathrm{A}^{\mathrm{b}}$ & N/A & N/A & N/A \\
\hline \multicolumn{7}{|l|}{ Follow-up } \\
\hline August '16 & $7207(2888)$ & $7063^{\mathrm{c}}(2565)$ & $23.20(1,228)$ & $<.001$ & $2.35(1,228)$ & .13 \\
\hline September' 16 & $7331(2546)$ & $7383(2479)$ & $15.81(1,228)$ & $<.001$ & $1.00(1,228)$ & .32 \\
\hline October' 16 & $7789(2754)$ & $7712(2493)$ & $0.04(1,228)$ & .84 & $2.46(1,228)$ & .12 \\
\hline November' 16 & $7924(3012)$ & $7654(2500)$ & $0.02(1,228)$ & .90 & $4.12(1,228)$ & $.04^{\mathrm{d}}$ \\
\hline December'16 & 8010 (2946) & 7427 (2434) & $0.19(1,228)$ & .67 & $11.36(1,228)$ & $.001^{\mathrm{d}}$ \\
\hline January '17 & $7613(3000)$ & $7343(2512)$ & $4.16(1,228)$ & $.04^{\mathrm{d}}$ & $3.39(1,228)$ & .07 \\
\hline February '17 & $7870(3086)$ & $7450(2497)$ & $0.71(1,228)$ & .40 & $6.55(1,228)$ & $.01^{\mathrm{d}}$ \\
\hline March '17 & $7547(2857)$ & $7398(2493)$ & $5.39(1,228)$ & $.02^{\mathrm{d}}$ & $2.52(1,228)$ & .11 \\
\hline
\end{tabular}

${ }^{\mathrm{a}}$ No violation of homogeneity of variance assumption between groups in any month occurred.

${ }^{\mathrm{b}}$ Not applicable.

${ }^{\mathrm{c}}$ Significantly deviated from normality (Shapiro-Wilk test: $P<.05$ ).

${ }^{\mathrm{d}} P<.05$. 
Figure 1. Mean daily step counts at baseline (June 2016) and follow-up (August 2016 to March 2017).

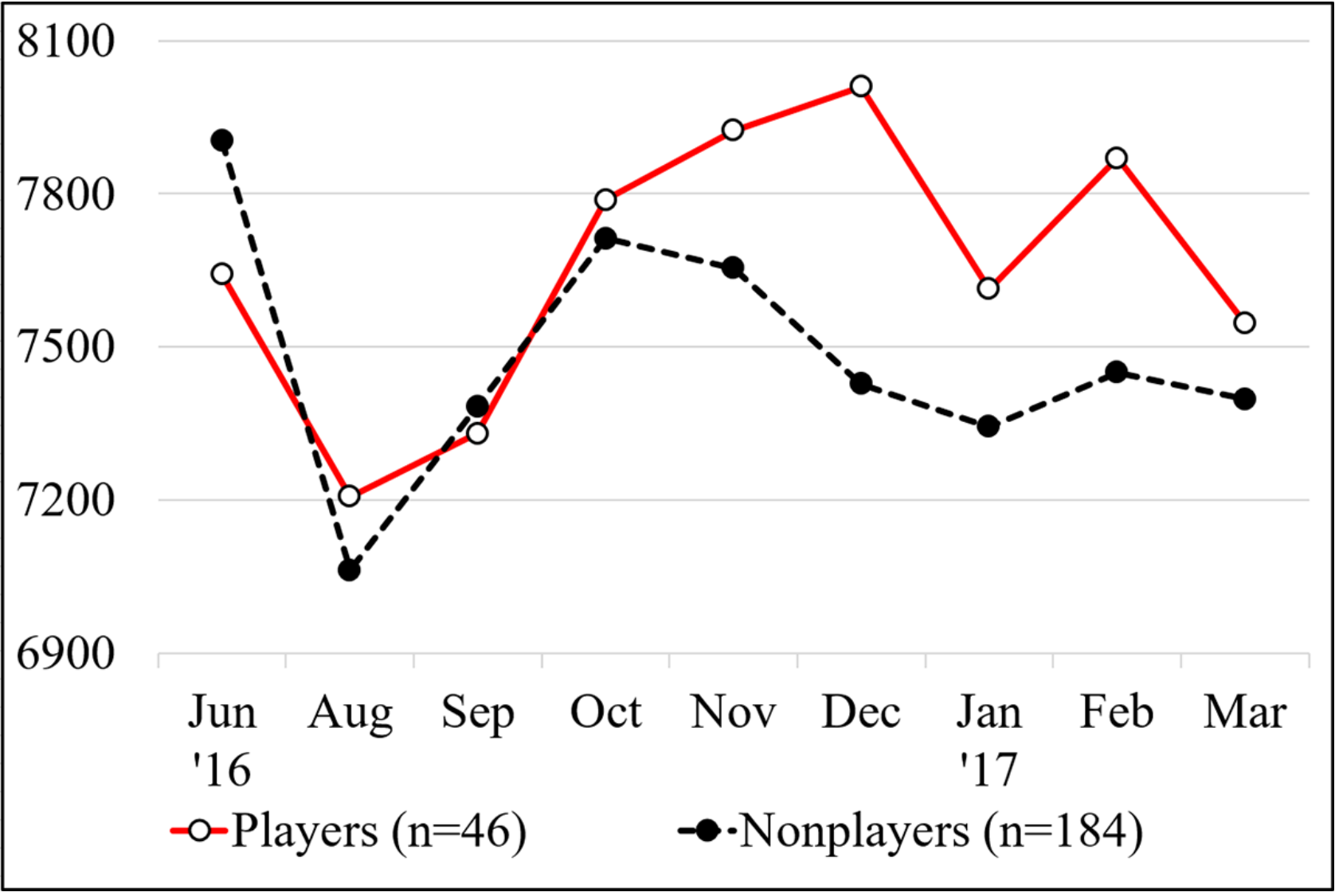

\section{Subgroup Analysis}

The results of the subgroup analyses are summarized in Table 3 (the complete results are presented in Multimedia Appendix 1). The interaction was significant for 3 months in men, but only 1 month in women. Regarding age, the interaction was significant for 7 of 8 months in the 55-64-year-old group but no month in the other two groups. In the 55-64-year-old group, the difference between players and nonplayers amounted to
1891 steps per day in December, whereas the difference was 320 steps per day at baseline. Regarding occupation, the interaction was significant for 2 months in workers and 1 month in nonworkers. Regarding PA level, the interaction was significant for 4 months in the active group, but only 1 month in the nonactive group. Finally, regarding subjective health status, the interaction was significant for 2 months in participants with good health and 1 month in others.

Table 3. $P$ value of interaction by subgroup analyses according to sex, age group, physical activity level, and subjective health status.

\begin{tabular}{|c|c|c|c|c|c|c|c|c|c|c|c|}
\hline \multirow[t]{2}{*}{ Time point } & \multicolumn{2}{|l|}{ Sex } & \multicolumn{3}{|c|}{ Age group (years) } & \multicolumn{2}{|c|}{ Occupation } & \multicolumn{2}{|c|}{ Physical activity level } & \multicolumn{2}{|c|}{ Health status } \\
\hline & $\begin{array}{l}\text { Male } \\
(\mathrm{n}=115)\end{array}$ & $\begin{array}{l}\text { Female } \\
(n=115)\end{array}$ & $\begin{array}{l}<55 \\
(\mathrm{n}=100)\end{array}$ & $\begin{array}{l}55-64 \\
(\mathrm{n}=80)\end{array}$ & $\begin{array}{l}\geq 65 \\
(\mathrm{n}=50)\end{array}$ & $\begin{array}{l}\text { Worker } \\
(\mathrm{n}=147)\end{array}$ & $\begin{array}{l}\text { Nonworker } \\
(\mathrm{n}=83)\end{array}$ & $\begin{array}{l}\text { Active } \\
(\mathrm{n}=85)\end{array}$ & $\begin{array}{l}\text { Nonactive } \\
(\mathrm{n}=145)\end{array}$ & $\begin{array}{l}\text { Good } \\
(\mathrm{n}=82)\end{array}$ & $\begin{array}{l}\text { Others } \\
(\mathrm{n}=148)\end{array}$ \\
\hline August '16 & .28 & .29 & .35 & $.03^{\mathrm{a}}$ & .24 & .08 & .96 & $.02^{\mathrm{a}}$ & .80 & .61 & .13 \\
\hline September '16 & .58 & .37 & .43 & .31 & .71 & .24 & .87 & .11 & .96 & .64 & .35 \\
\hline October' 16 & .36 & .18 & .60 & $.007^{\mathrm{a}}$ & .73 & .19 & .27 & $.02^{\mathrm{a}}$ & .81 & .22 & .31 \\
\hline November'16 & $.03^{\mathrm{a}}$ & .64 & .77 & $.005^{\mathrm{a}}$ & .77 & $.02^{\mathrm{a}}$ & .86 & .11 & .17 & $.02^{\mathrm{a}}$ & .54 \\
\hline December' 16 & $.02^{\mathrm{a}}$ & $.01^{\mathrm{a}}$ & .31 & $.001^{\mathrm{a}}$ & .23 & $.02^{\mathrm{a}}$ & $.01^{\mathrm{a}}$ & $.01^{\mathrm{a}}$ & $.02^{\mathrm{a}}$ & $.01^{\mathrm{a}}$ & $.03^{\mathrm{a}}$ \\
\hline January '17 & .06 & .67 & .61 & $.02^{\mathrm{a}}$ & .94 & .08 & .39 & .30 & .13 & .10 & .31 \\
\hline February '17 & $.006^{\mathrm{a}}$ & .48 & .71 & $.008^{\mathrm{a}}$ & .24 & .07 & .08 & .07 & .07 & .06 & .08 \\
\hline March '17 & .09 & .70 & .93 & $.02^{\mathrm{a}}$ & .99 & .12 & .66 & $.02^{\mathrm{a}}$ & .84 & .36 & .20 \\
\hline
\end{tabular}

${ }^{\mathrm{a}} P<.05$. 


\section{Discussion}

\section{Principal Findings}

This study confirmed the difference in step counts between players and nonplayers before and after the release of Pokémon GO. On analyzing all samples, we observed that step counts were significantly high even in February 2017, 7 months after the release of the game, which was not observed in previous short-term studies. Players did not decrease their step counts even in cold months, unlike nonplayers and other YWPP participants [46].

In subgroup analyses, step counts of the 55-64-year-old group were significantly high until the last surveyed month. This finding, along with the result that significantly higher step counts were noted in men and workers than in women and nonworkers, indicates that older, middle-aged male workers may take long, indirect routes to visit Pokéstops and Gyms for catching rare Pokémon on their way to the work place, visiting other places, and while going home. This result is in accordance with a previous finding, according to which people did not change their daily routines but slightly modified them to play the game [21]. Although the higher step counts of players aged $\geq 65$ years was not significant in any month in this study, some senior citizen's clubs in Japan have promoted Pokémon GO to increase outdoor activities, as older people continue to play the game despite its diminishing popularity among younger players [48]. Such trials are recommended along with the development of additional location-based augmented reality games following Pokémon GO [49] for young people who lose interest quickly.

\section{Comparison With Previous Studies}

Previous studies have observed short-term effects on the PA of young people $[30,31,33,44]$. For example, a US study conducted in survey participants aged 18-35 years reported that the difference in daily step counts between players and nonplayers was approximately 1000 in the first week after installation of Pokémon GO [39]. The difference in this study was smaller (583 steps in December, at most), which may be because the players were older and did not play the game as intensely as younger players or because the analysis was conducted for each month and a short-term difference may have been overlooked. We observed significantly higher step counts in more months in the active group than in the nonactive group, unlike a previous study in which it was reported that players with a lower baseline PA level had increased PA [40,42]. In addition, it may be due to the difference in sample characteristics and length of the study period.

\section{Limitations}

Our study had some limitations. First, all characteristics of the study sample could not be simultaneously considered because of the limited number of participants who played the game. If there were more participants, we could have specified in more detail those who increased their step counts and continued to play the game. Their motivations for taking part in the YWPP, such as family structure and living area, should be considered as well. Second, the distribution of step counts in some subgroups did not meet the assumptions of normality and homogeneity of variance. The results of these analyses might not be as valid as those of others, although the $F$ test is considered to be robust for nonnormal data [50]. Third, it is unclear whether the results of this study depend on the characteristics of the country, city, or participants. Further studies under different conditions are required to further examine the results. Fourth, there was a lack of variables regarding when, where, and why the participants played Pokémon GO, besides their intensity for the game, such as playing time or experience points in the game [40]. Finally, the effect on physical and psychological health, other than step counts, was not confirmed. Its negative impact, especially accidents [51-53] and injury [54,55], should be considered as well. However, our study demonstrated the potential of location-based augmented reality apps in promoting PA for a longer period than expected in the literature, at least for particular groups.

\section{Conclusions}

This study confirmed the difference in step counts between players and nonplayers before and after the release of Pokémon GO. According to our analysis, step counts were higher until 7 months after the release. The player group maintained their step counts in winter, despite the decrease in step counts of nonplayers. In subgroup analyses, players were more likely to be men, aged $<55$ years, workers, active, and subjectively in good health.

\section{Acknowledgments}

This study was funded by the Japan Society for the Promotion of Science KAKENHI, grant numbers 25242063, 26249073, and $18 \mathrm{H} 01602$.

\section{Authors' Contributions}

All authors contributed to the study design and data interpretation. KH contributed to data collection and data analysis. KH wrote the first draft, and YA and JSL critically reviewed the manuscript. All authors approved the final version of the manuscript.

\section{Conflicts of Interest}

None declared.

\section{Multimedia Appendix 1}

The full results of subgroup analysis by sex, age group, physical activity level, and subjective health status. 
[PDF File (Adobe PDF File), 98KB-Multimedia Appendix 1]

\section{References}

1. Kamboj AK, Krishna SG. Pokémon GO: An innovative smartphone gaming application with health benefits. Prim Care Diabetes 2017 Dec;11(4):397-399. [doi: 10.1016/j.pcd.2017.03.008] [Medline: 28457897]

2. Penedo FJ, Dahn JR. Exercise and well-being: a review of mental and physical health benefits associated with physical activity. Curr Opin Psychiatry 2005 Mar;18(2):189-193. [Medline: 16639173]

3. Conroy DE, Yang C, Maher JP. Behavior change techniques in top-ranked mobile apps for physical activity. Am J Prev Med 2014 Jun;46(6):649-652. [doi: 10.1016/j.amepre.2014.01.010] [Medline: 24842742]

4. Yang C, Maher JP, Conroy DE. Implementation of behavior change techniques in mobile applications for physical activity. Am J Prev Med 2015 Apr;48(4):452-455. [doi: 10.1016/j.amepre.2014.10.010] [Medline: 25576494]

5. Bort-Roig J, Gilson ND, Puig-Ribera A, Contreras RS, Trost SG. Measuring and influencing physical activity with smartphone technology: a systematic review. Sports Med 2014 May;44(5):671-686. [doi: 10.1007/s40279-014-0142-5] [Medline: 24497157]

6. Fukuoka Y, Vittinghoff E, Jong SS, Haskell W. Innovation to motivation--pilot study of a mobile phone intervention to increase physical activity among sedentary women. Prev Med 2010;51(3-4):287-289 [FREE Full text] [doi: 10.1016/j.ypmed.2010.06.006] [Medline: 20600263]

7. Kirwan M, Duncan MJ, Vandelanotte C, Mummery WK. Using smartphone technology to monitor physical activity in the 10,000 Steps program: a matched case-control trial. J Med Internet Res 2012 Apr 20;14(2):e55 [FREE Full text] [doi: 10.2196/jmir.1950] [Medline: 22522112]

8. Swatman R. Guinness World Records. 2016 Aug 26. Pokémon Go catches five new world records Internet URL: http:/ /www.guinnessworldrecords.com/news/2016/8/pokemon-go-catches-five-world-records-439327 [accessed 2018-03-21] [WebCite Cache ID 6yUfaCUN7]

9. Leswing K. Business Insider. 2016 Jul 26. Pokemon Go has been dethroned as the top free iPhone app-by Snapchat's $\$ 100$ million stickers URL: http://www.businessinsider.com/ pokemon-go-has-been-dethroned-as-the-top-free-app-by-snapchats-100-million-stickers-2016-7 [accessed 2018-03-21] [WebCite Cache ID 6yUfo35eT]

10. Tang AK. Key factors in the triumph of Pokémon GO. Business Horizons 2017 Sep;60(5):725-728. [doi: 10.1016/j.bushor.2017.05.016]

11. American Heart Association News. 2016 Jul 19. Pokémon Go brings video games outside URL: https://news.heart.org/ pokemon-go-brings-video-games-outside/ [accessed 2018-04-07] [WebCite Cache ID 6yUfpzSPG]

12. Ayers JW, Leas EC, Dredze M, Allem J, Grabowski JG, Hill L. Pokémon GO-A New Distraction for Drivers and Pedestrians. JAMA Intern Med 2016 Dec 01;176(12):1865-1866. [doi: 10.1001/jamainternmed.2016.6274] [Medline: 27635638]

13. Clark AM, Clark MTG. Pokémon Go and Research. International Journal of Qualitative Methods 2016 Aug 29;15(1):160940691666776. [doi: 10.1177/1609406916667765]

14. McCartney M. Margaret McCartney: Game on for Pokémon Go. BMJ 2016 Aug 09;354:i4306. [doi: 10.1136/bmj.i4306] [Medline: 27510374]

15. Williamson JW. Will the 'Pokémon' be Heroes in the Battle Against Physical Inactivity? Sport Exerc Med Open J 2016 Sep 14;2(1):13-14. [doi: 10.17140/SEMOJ-2-133]

16. Ghosh A, Misra A. Pokémon Go, Obesity and Diabetes: A Perspective from India. Diabetes Technol Ther 2016 Dec;18(11):725-726. [doi: 10.1089/dia.2016.0303] [Medline: 27753510]

17. LeBlanc AG, Chaput J. Pokémon Go: A game changer for the physical inactivity crisis? Prev Med 2017 Aug;101:235-237. [doi: 10.1016/j.ypmed.2016.11.012] [Medline: 27856340]

18. Niantic, Inc. 2016 Sep 07. Heads Up! URL: https://www.nianticlabs.com/blog/headsup/ [accessed 2018-03-21] [WebCite Cache ID 6yUfwC2qC]

19. Krittanawong C, Aydar M, Kitai T. Pokémon Go: digital health interventions to reduce cardiovascular risk. Cardiol Young 2017 Oct;27(8):1625-1626. [doi: 10.1017/S1047951117000749] [Medline: 28414007]

20. Wang D, Wu T, Wen S, Liu D, Xiang Y, Zhou W, et al. Pokémon GO in Melbourne CBD: A case study of the cyber-physical symbiotic social networks. Journal of Computational Science 2018 May;26:456-467. [doi: 10.1016/j.jocs.2017.06.009]

21. Graells-Garrido E, Ferres L, Caro D, Bravo L. The effect of Pokémon Go on the pulse of the city: a natural experiment. EPJ Data Sci 2017 Sep 15;6(1):a. [doi: 10.1140/epjds/s13688-017-0119-3]

22. Wasmuth EV, Lima CD. The Rrp6 C-terminal domain binds RNA and activates the nuclear RNA exosome. Nucleic Acids Res 2017 Dec 25;45(2):846-860 [FREE Full text] [doi: 10.1093/nar/gkw1152] [Medline: 27899565]

23. Zsila Á, Orosz G, BÅ ‘the B, Tóth-Király I, Király O, Griffiths M, et al. An empirical study on the motivations underlying augmented reality games: The case of Pokémon Go during and after Pokémon fever. Personality and Individual Differences 2017 Jun:-. [doi: 10.1016/j.paid.2017.06.024]

24. Rauschnabel P, Rossmann A, tom Dieck MC. An adoption framework for mobile augmented reality games: The case of Pokémon Go. Computers in Human Behavior 2017 Nov;76:276-286. [doi: 10.1016/j.chb.2017.07.030] 
25. Marquet O, Alberico C, Adlakha D, Hipp JA. Examining Motivations to Play Pokémon GO and Their Influence on Perceived Outcomes and Physical Activity. JMIR Serious Games 2017 Oct 24;5(4):e21 [FREE Full text] [doi: 10.2196/games.8048] [Medline: 29066423]

26. Watanabe K, Kawakami N, Imamura K, Inoue A, Shimazu A, Yoshikawa T, et al. Pokémon GO and psychological distress, physical complaints, and work performance among adult workers: a retrospective cohort study. Sci Rep 2017 Sep 07;7(1):10758 [FREE Full text] [doi: 10.1038/s41598-017-11176-2] [Medline: 28883633]

27. Bonus JA, Peebles A, Mares M, Sarmiento IG. Look on the Bright Side (of Media Effects): Pokémon Go as a Catalyst for Positive Life Experiences. Media Psychology 2017 Apr 07;21(2):263-287. [doi: 10.1080/15213269.2017.1305280]

28. Oleksy T, Wnuk A. Catch them all and increase your place attachment! The role of location-based augmented reality games in changing people - place relations. Computers in Human Behavior 2017 Nov;76:3-8. [doi: 10.1016/j.chb.2017.06.008]

29. Zach FJ, Tussyadiah IP. To Catch Them All—The (Un)intended Consequences of Pokémon GO on Mobility, Consumption, and Wellbeing. In: Schegg R, Stangl B, editors. Information and Communication Technologies in Tourism 2017. Cham, Switzerland: Springer; 2017:217-227.

30. Barkley JE, Lepp A, Glickman EL. "Pokémon Go!” May Promote Walking, Discourage Sedentary Behavior in College Students. Games Health J 2017 Jun;6(3):165-170. [doi: 10.1089/g4h.2017.0009] [Medline: 28628384]

31. Wong FY. Influence of Pokémon Go on physical activity levels of university players: a cross-sectional study. Int $\mathbf{J}$ Health Geogr 2017 Dec 22;16(1):8 [FREE Full text] [doi: 10.1186/s12942-017-0080-1] [Medline: 28228102]

32. Liu W, Ligmann-Zielinska A. A Pilot Study of Pokémon Go and Players' Physical Activity. Games Health J 2017 Dec;6(6):343-350. [doi: 10.1089/g4h.2017.0036] [Medline: 28853912]

33. Nigg CR, Mateo DJ, An J. Pokémon GO May Increase Physical Activity and Decrease Sedentary Behaviors. Am J Public Health 2017 Jan;107(1):37-38. [doi: 10.2105/AJPH.2016.303532] [Medline: 27854536]

34. Kogan L, Hellyer P, Duncan C, Schoenfeld-Tacher R. A pilot investigation of the physical and psychological benefits of playing Pokémon GO for dog owners. Computers in Human Behavior 2017 Nov;76:431-437. [doi: 10.1016/j.chb.2017.07.043]

35. Colpani V, Spritzer PM, Lodi AP, Dorigo GG, Miranda IASD, Hahn LB, et al. Physical activity in climacteric women: comparison between self-reporting and pedometer. Rev Saude Publica 2014 Apr;48(2):258-265 [FREE Full text] [Medline: 24897047]

36. Sabia S, van Hees VT, Shipley MJ, Trenell MI, Hagger-Johnson G, Elbaz A, et al. Association between questionnaire- and accelerometer-assessed physical activity: the role of sociodemographic factors. Am J Epidemiol 2014 Mar 15;179(6):781-790 [FREE Full text] [doi: 10.1093/aje/kwt330] [Medline: 24500862]

37. Senso MM, Anderson CP, Crain AL, Sherwood NE, Martinson BC. Self-reported activity and accelerometry in 2 behavior-maintenance trials. Am J Health Behav 2014 Mar;38(2):254-264 [FREE Full text] [doi: 10.5993/AJHB.38.2.11] [Medline: 24629554]

38. Tudor-Locke C, Johnson WD, Katzmarzyk PT. Relationship between accelerometer-determined steps/day and other accelerometer outputs in US adults. J Phys Act Health 2011 Mar;8(3):410-419. [Medline: 21487141]

39. Howe KB, Suharlim C, Ueda P, Howe D, Kawachi I, Rimm EB. Gotta catch'em all! Pokémon GO and physical activity among young adults: difference in differences study. BMJ 2016 Dec 13;355:i6270 [FREE Full text] [doi: 10.1136/bmj.i6270] [Medline: 27965211]

40. Xian Y, Xu H, Xu H, Liang L, Hernandez AF, Wang TY, et al. An Initial Evaluation of the Impact of Pokémon GO on Physical Activity. J Am Heart Assoc 2017 May 16;6(5):pii: e005341 [FREE Full text] [doi: 10.1161/JAHA.116.005341] [Medline: 28512111]

41. Duncan MJ, Wunderlich K, Zhao Y, Faulkner G. Walk this way: validity evidence of iphone health application step count in laboratory and free-living conditions. J Sports Sci 2018 Aug;36(15):1695-1704. [doi: 10.1080/02640414.2017.1409855] [Medline: 29179653]

42. Althoff T, White RW, Horvitz E. Influence of Pokémon Go on Physical Activity: Study and Implications. J Med Internet Res 2016 Dec 06;18(12):e315 [FREE Full text] [doi: 10.2196/jmir.6759] [Medline: 27923778]

43. Freeman B, Chau J, Mihrshahi S. Why the public health sector couldn't create Pokémon Go. Public Health Res Pract 2017 Jul 26;27(3):pii: 2731724 [FREE Full text] [doi: 10.17061/phrp2731724] [Medline: 28765857]

44. Marquet O, Alberico C, Hipp AJ. Pokémon GO and physical activity among college students. A study using Ecological Momentary Assessment. Computers in Human Behavior 2018 Apr;81:215-222. [doi: 10.1016/j.chb.2017.12.028]

45. Caspersen CJ, Pereira MA, Curran KM. Changes in physical activity patterns in the United States, by sex and cross-sectional age. Med Sci Sports Exerc 2000 Sep;32(9):1601-1609. [Medline: 10994912]

46. Hino K, Lee JS, Asami Y. Associations between seasonal meteorological conditions and the daily step count of adults in Yokohama, Japan: Results of year-round pedometer measurements in a large population. Prev Med Rep 2017 Dec;8:15-17 [FREE Full text] [doi: 10.1016/j.pmedr.2017.07.009] [Medline: 28831368]

47. Ministry of Health, Labour and Welfare. 2012. Health Japan 21 (second) URL: https://www.mhlw.go.jp/stf/seisakunitsuite/ bunya/kenkou iryou/kenkou/kenkounippon21.html[WebCite Cache ID 6yUg2aiGt]

48. Kyodo News. 2017 Jul 15. One year after release, Pokemon Go is fitness tool for older people URL: https://english. kyodonews.net/news/2017/07/2260c4fc6b84-feature-one-year-after-release-pokemon-go-is-fitness-tool-for-older-people. html[WebCite Cache ID 6yUh6tOoO] 
49. Kamel Boulos MN, Lu Z, Guerrero P, Jennett C, Steed A. From urban planning and emergency training to Pokémon Go: applications of virtual reality GIS (VRGIS) and augmented reality GIS (ARGIS) in personal, public and environmental health. Int J Health Geogr 2017 Dec 20;16(1):7 [FREE Full text] [doi: 10.1186/s12942-017-0081-0] [Medline: 28219378]

50. Blanca MJ, Alarcón R, Arnau J, Bono R, Bendayan R. Non-normal data: Is ANOVA still a valid option? Psicothema 2017 Nov;29(4):552-557. [doi: 10.7334/psicothema2016.383] [Medline: 29048317]

51. Barbieri S, Vettore G, Pietrantonio V, Snenghi R, Tredese A, Bergamini M, et al. Pedestrian Inattention Blindness While Playing Pokémon Go as an Emerging Health-Risk Behavior: A Case Report. J Med Internet Res 2017 Dec 01;19(4):e86 [FREE Full text] [doi: 10.2196/jmir.6596] [Medline: 28365563]

52. Joseph B, Armstrong DG. Potential perils of peri-Pokémon perambulation: the dark reality of augmented reality? Oxf Med Case Reports 2016 Oct;2016(10):omw080 [FREE Full text] [doi: 10.1093/omcr/omw080] [Medline: 27713831]

53. Wagner-Greene VR, Wotring AJ, Castor T, Kruger J, Mortemore S, Dake JA. Pokémon GO: Healthy or Harmful? Am J Public Health 2017 Jan;107(1):35-36. [doi: 10.2105/AJPH.2016.303548] [Medline: 27925813]

54. Anderson N, Steele J, O'Neill L, Harden LA. Pokémon Go: mobile app user guides. Br J Sports Med 2016 Aug 18;51(20):1505-1506. [doi: 10.1136/bjsports-2016-096762]

55. Serino M, Cordrey K, McLaughlin L, Milanaik RL. Pokémon Go and augmented virtual reality games: a cautionary commentary for parents and pediatricians. Curr Opin Pediatr 2016 Dec;28(5):673-677. [doi: 10.1097/MOP.0000000000000409] [Medline: 27479151]

\section{Abbreviations \\ PA: physical activity \\ YWPP: Yokohama Walking Point Program}

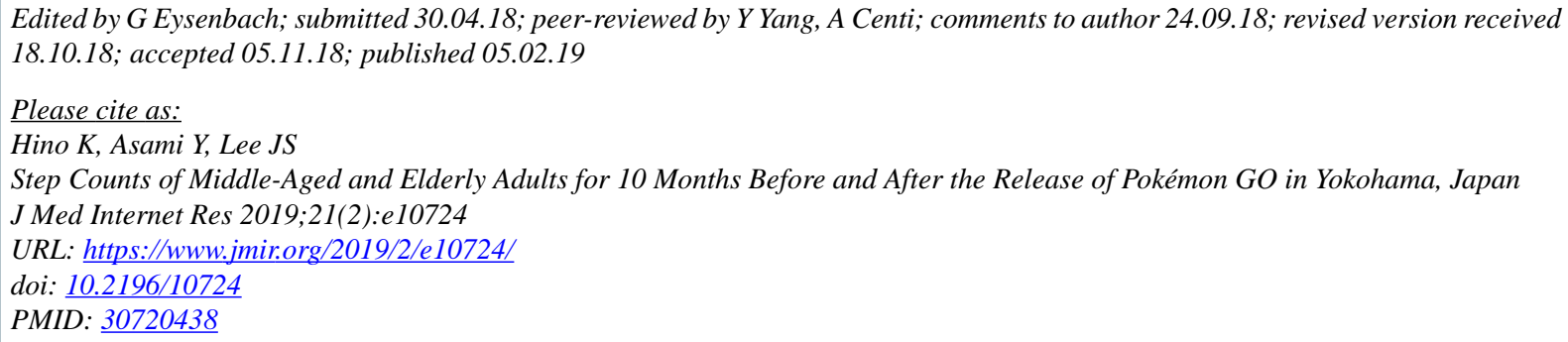

CKimihiro Hino, Yasushi Asami, Jung Su Lee. Originally published in the Journal of Medical Internet Research (http://www.jmir.org), 05.02.2019. This is an open-access article distributed under the terms of the Creative Commons Attribution License (https://creativecommons.org/licenses/by/4.0/), which permits unrestricted use, distribution, and reproduction in any medium, provided the original work, first published in the Journal of Medical Internet Research, is properly cited. The complete bibliographic information, a link to the original publication on http://www.jmir.org/, as well as this copyright and license information must be included. 